\title{
Effects of land-use change on carbon stocks in Switzerland
}

\section{Journal Article}

Author(s):

Bolliger, Janine; Hagedorn, Frank; Leifeld, Jens; Böhl, Jürgen; Zimmermann, Stephan; Soliva, Reto; Kienast, Felix

Publication date:

2008-09-01

Permanent link:

https://doi.org/10.3929/ethz-b-000070469

Rights / license:

In Copyright - Non-Commercial Use Permitted

Originally published in:

Ecosystems 11(6), https://doi.org/10.1007/s10021-008-9168-6 


\title{
Effects of Land-Use Change on Carbon Stocks in Switzerland
}

\author{
Janine Bolliger, ${ }^{1 *}$ Frank Hagedorn, ${ }^{1}$ Jens Leifeld, ${ }^{2}$ Jürgen Böhl, ${ }^{1}$ \\ Stephan Zimmermann, ${ }^{1}$ Reto Soliva, ${ }^{1}$ and Felix Kienast ${ }^{1}$
}

${ }^{1}$ Swiss Federal Research Institute WSL, Zücherstrasse 111, 8903 Birmensdorf, Switzerland; ${ }^{2}$ Research Station Agroscope ReckenholzTänikon ART, Reckenholzstrasse 191, 8046 Zurich, Switzerland

\begin{abstract}
We assessed how consequences of future land-use change may affect size and spatial shifts of C stocks under three potential trends in policy-(a) business-as-usual: continuation of land-use trends observed during the past 15 years; (b) extensification: full extensification of open-land; and (c) liberalization: full reforestation potential. The build-up times for the three scenarios are estimated at 30, 80 and 100 years, respectively. Potential C-stock change rates are derived from the literature. Whereas the business-as-usual scenario would cause marginal changes of $0.5 \%$, liberalization would provoke a $13 \%$ increase in C stocks $(+62 \mathrm{MtC})$. Gains of $24 \%$ would be expected for forests $(+95 \mathrm{MtC})$, whereas open-land $\mathrm{C}$ stock would decrease $27 \%(-33 \mathrm{MtC})$. Extensification would lead to a C stock decrease of 3\% (-12 MtC). Whereas forest $\mathrm{C}$ is expected to increase $12 \%$ $(+36.5 \mathrm{MtC})$ at high elevations, stocks of open-land
\end{abstract}

\section{INTRODUCTION}

The dominant land uses in Europe include agriculture and forestry with area coverage of 45 and $36 \%$, respectively (FAO 2003). Between 1961 and 2000, European agricultural land has declined approximately 13\% (Rounsevell and others 2003, 2006), whereas European forests have been expanding (Kankaapää and Carter 2004). Further, these change due to shifts in economic conditions

Received 2 November 2007; accepted 2 June 2008; published online 18 July 2008

*Corresponding author; e-mail: Janine.bolliger@wsl.ch
C would decline $38.5 \%(-48.5 \mathrm{MtC})$. Most affected are unfavorable grasslands, which increase in area (+59\%) but contribute only $14.5 \%$ to the C stocks.

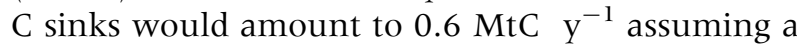
build-up time of 100 years for the liberalization scenario. C stocks on the current forest area are increasing by $1 \mathrm{MtC} \mathrm{y}^{-1}$. The maximal total C sink of 1.6 MtC might thus suffice to compensate for agricultural greenhouse gases (2004: 1.4 Mt $\mathrm{CO}_{2}-\mathrm{C}$ equivalents), but corresponds only to $11-13 \%$ of the anthropogenic greenhouse gas emission in Switzerland. Thus, even the largest of the expected terrestrial C stocks under liberalization will be small in comparison with current emissions of anthropogenic greenhouse gases.

Key words: agroecosystem change; agricultural decline; C stock; land-use change; forest C; openland C; soil C; scenario-based modeling. and management of agriculture and forestry have been consistently observed across Europe (Labaune and Magnin 2002; Dirnböck and others 2003; Dullinger and others 2003; Laiolo and others 2004; van der Vaart 2005). In marginal and mountainous regions, economic development has resulted in abandonment of low-intensity agriculture (Meeus and others 1991; Bätzig 1996; Maurer and others 2006), decreasing total grassland area and increasing forest coverage (Tasser and Tappeiner 2002; Lindborg and Eriksson 2004).

Changes in land use affect $\mathrm{C}$ stocks in terrestrial ecosystems and thus management of land may be 
an important mitigation strategy for reducing atmospheric $\mathrm{CO}_{2}$ concentrations. The historical cumulative $\mathrm{C}$ losses due to global land-use changes prior to 1850 have been estimated as $180-220 \mathrm{PgC}$ (DeFries and others 1999; IPCC 2001), which almost equals the cumulative fossil fuel emissions since pre-industrial times of 280 PgC (IPCC 2001). Currently, terrestrial ecosystems of the northern mid-latitudes are a substantial sink for atmospheric $\mathrm{CO}_{2}$ as indicated by coupled atmospheric transport models and stable isotopes composition (Ciais and others 1995; Houghton 2003). The reasons for this $\mathrm{C}$ sink are not completely understood, but it is very likely a combination of a growth enhancement of plants through increasing atmospheric $\mathrm{CO}_{2}$ concentrations, $\mathrm{N}$ deposition, and increasing temperatures, as well as rising C stocks in forests through agricultural abandonment and declining wood harvest (Ciais and others 1995; Townsend and others 1996; Liski and others 2002; Houghton 2003). Europe's terrestrial ecosystems currently take up $7-12 \%$ of anthropogenic $\mathrm{CO}_{2}$ emissions, with forests being the most important $\mathrm{C}$ sink (Janssens and others 2003). Trends in a country's C stocks are significant because the Kyoto protocol provides the possibility to credit emission reductions by forestry and agricultural activities to increase $\mathrm{C}$ stocks in ecosystems. This requires overall landscape-scale and spatially explicit estimations of $\mathrm{C}$ stocks as baseline information to assess likely $\mathrm{C}$ stock changes and to identify potential future sinks and sources.

In this article we estimate the magnitude and expected spatial shifts of $\mathrm{C}$ stocks (forest and agroecosystem soils, forest biomass) for three scenarios of land-use change in Switzerland (extent: $41,000 \mathrm{~km}^{2}$, grain: $1 \mathrm{ha}$ ). Additionally, rough estimates on the rates of $\mathrm{C}$-stock changes are addressed based on literature values. Our assessment relies on a compilation of data from various sources for different land-use types (forest biomass and soils, intensively and extensively managed agricultural land (soils)). We estimate C-stock changes based on: (a) business-as-usual, (b) liberalization, and (c) extensification. These scenarios represent the effects of socio-economic factors on land use, arising from societal support (state/federal subsidies) to agriculture and to conservation efforts. The business-as-usual scenario extrapolates trends of landuse change observed during 1985-1997 into the future. The liberalization scenario relies on the assumption that no public support is given to either agriculture or conservation with fully liberalized agricultural markets. The extensification scenario supports extensively managed open-land based on state/federal subsidies. We estimated the build-up times for the three scenarios to 30, 100, and 80 years, respectively.

The following questions are addressed: What are the potential effects of socio-economically driven land-use changes on terrestrial C sinks in Switzerland? What are the implications of various land-use change scenarios on the spatial distribution of $\mathrm{C}$ stocks?

\section{Materials ANd Methods}

\section{Study Area}

Switzerland covers an area of approximately $41,000 \mathrm{~km}^{2}$, of which $36.9 \%$ is agricultural $30.8 \%$ is forested, $25.5 \%$ is unproductive areas, and $6.8 \%$ is settlement and urban areas (Statistisches Jahrbuch der Schweiz 1997; Swiss Federal Statistical Office 2001). Switzerland's resident population amounted to roughly 7 million in 1997.

Switzerland can be divided into five ecoregions, which differ in climate, geology, and land use: the Jura mountains, the Plateau (lowlands), the Northern Alps, Central Alps, and the Southern Alps (Figure 1). The land use of these ecoregions differs considerably (Swiss Federal Statistical Office 2001). The Jura is dominated by forests and agriculture, whereas settlements and unproductive areas play a minor role (Table 1). The Plateau is primarily shaped by agricultural land use, followed by forests, settlements, and unproductive areas (Table 1). Northern Alpine landscapes are dominated by agricultural land, forests, and unproductive areas. Fifty percent of the Central Alps are unproductive and the remaining area is shaped by agricultural land use and forests (Table 1). The south of the Alps is dominated by forests, unproductive areas, and settlements, whereas agricultural land covers only minor areas (Table 1).

\section{Scenarios of Land-Use Change}

We identified three scenarios of land-use change: business-as-usual, liberalization, and extensification. Detailed descriptions of the scenarios and their development can be found in Bolliger and others (2007). The scenarios are spatially explicit, static projections of change based on categorical land-use data and on socio-economic considerations. These projections are static, thus explicit build-up times cannot be identified. Our implicit estimations, however, range from 30 years for the business-as-usual scenario, 80 years for the extensification, and 100 years for the liberalization scenario. The scenarios rely on land-use data for two 


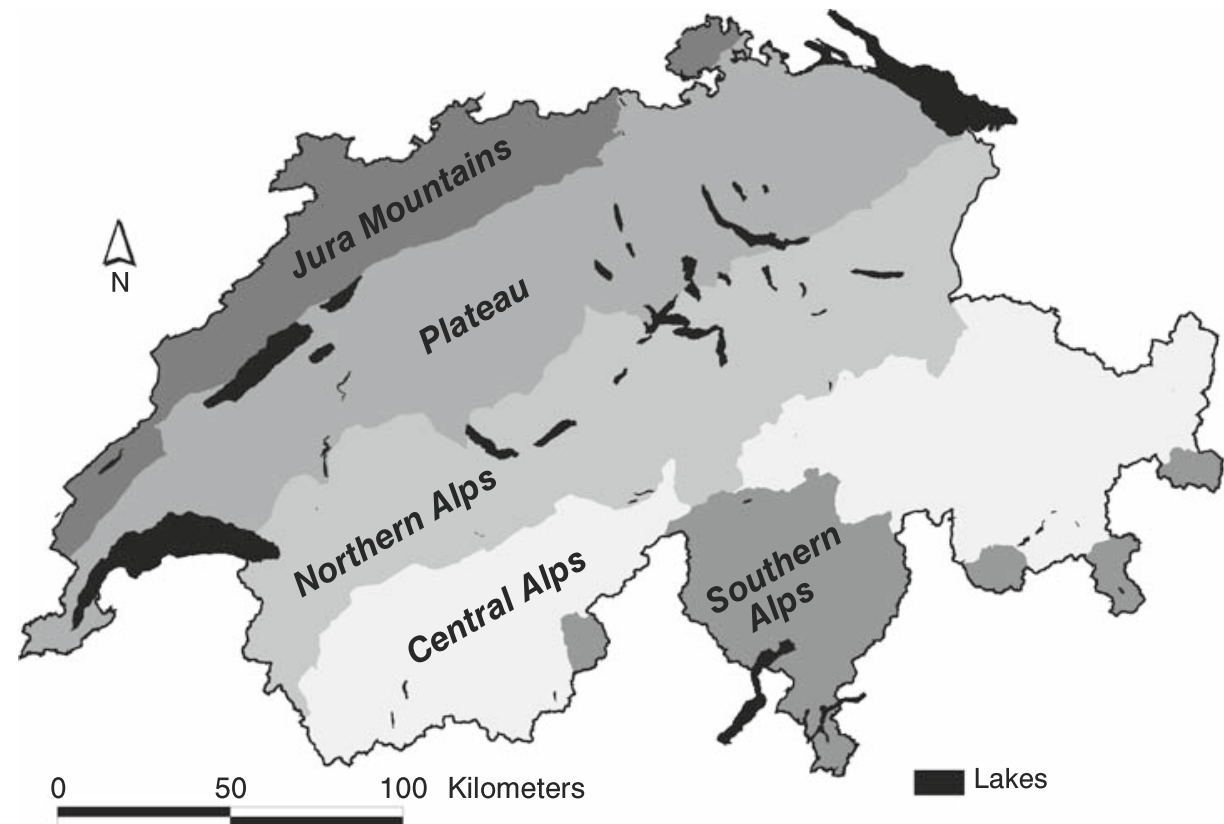

Figure 1. The study area of Switzerland and its five major bioclimatic and biogeographic regions.

Table 1. Land Use of the Five Major Ecoregions of Switzerland

\begin{tabular}{llc}
\hline Ecoregion & Land use type & $\%$ Area \\
\hline Jura & Forest & 47.7 \\
& Agriculture & 44 \\
& Settlement & 7.4 \\
Total & Unproductive & 1 \\
Plateau & Forest & 100 \\
& Agriculture & 25.4 \\
& Settlement & 50 \\
Total & Unproductive & 14.6 \\
Northern Alps & & 10 \\
& Forest & 100 \\
& Agriculture & 33.2 \\
Total & Settlement & 38.2 \\
Central Alps & Unproductive & 4 \\
& & 24.6 \\
& Forest & 100 \\
Total & Agriculture & 22.2 \\
Southern Alps & Settlement & 25.6 \\
& Unproductive & 2.2 \\
& & 50 \\
Swiss Federal Statistical Office & Forest & 100 \\
\hline & Agriculture & 47.2 \\
& Settlement & 13.9 \\
& Unproductive & 4.3 \\
& & 34.6 \\
& & 100 \\
& & \\
& & \\
& & \\
& & \\
& &
\end{tabular}

periods (1979-1985 and 1992-1997) and cover Switzerland at a resolution of 1 ha (BFS 1979/85, 1992/97). Originally, the land-use data were categorized into 74 land-use classes. We aggregated these into five categories that were relevant for land-use change assessments: forest, open forest, scrub, intensively and extensively managed openland (Table 2).

We calculated transitions in land use for the five land-use classes that occurred between the two periods 1985 and 1997 (Rutherford and others 2008). We expressed the 25 possible transitions in land use in cells of a $5 \times 5$ table, with each cell representing a transition between two land-use types, or no change in use (Rutherford and others 2008). The transition probabilities yield the probability of any pixel with land-use type $x$ to be transformed to land-use type $y$. For each land use transition, a logistic regression model was calibrated for the categories forest, open forest, scrub, non-intensively used and intensively used open land based on a selection out of 27 variables. The variables include sets of climate, soil, relief, neighborhood (for example, number of neighboring pixels characterized by "closed forest"), and distance variables (for example, distance to "closed forest") (Rutherford and others 2008). The proportion of variance explained differed between models but a consistently high AUC (area under the curve) for both calibration and evaluation datasets was achieved, with values ranging from 0.58 to 0.96 (Rutherford and others 2008).

We assumed that public support of agricultural and conservation are the major drivers of land-use change and identified three scenarios (Bolliger and others 2007). The business-as-usual scenario assumes a linear continuation of observed changes 
Table 2. Aggregated Land-Use Categories

\begin{tabular}{|c|c|c|}
\hline $\begin{array}{l}\text { Aggregated } \\
\text { class }\end{array}$ & Original classes (class number) & Description \\
\hline Forest & $\begin{array}{l}\text { Other forest, normal forest, strips, blocks, } \\
\text { bushes, groves, hedges }\end{array}$ & $\begin{array}{l}\text { Vegetation height }>3 \mathrm{~m} \text {, density }>60 \% \text {, composed of } \\
\text { tree species }\end{array}$ \\
\hline Open forest & $\begin{array}{l}\text {... on non-agriculturally used land, on } \\
\text { agriculturally used land, groups of trees } \\
\text { on agriculturally used land, other groves }\end{array}$ & $\begin{array}{l}\text { Vegetation height }>3 \mathrm{~m} \text {, density } 20-60 \% \text {, composed } \\
\text { of tree species }\end{array}$ \\
\hline $\begin{array}{l}\text { Non-intensive } \\
\text { open land }\end{array}$ & $\begin{array}{l}\text { Pasture in vicinity of settlements, 'Mai- } \\
\text { ensässe', hay alps, mountain meadows, } \\
\text { sheep alps, favorable to pasturing, stony } \\
\text { alpine pasture, grass, herb vegetation }\end{array}$ & $\begin{array}{l}\text { Used for grazing, use not necessarily year-round, } \\
\text { mostly not machine-accessible }\end{array}$ \\
\hline $\begin{array}{l}\text { Intensive open } \\
\text { land }\end{array}$ & $\begin{array}{l}\text { Machine accessible meadows, meadows, } \\
\text { limited machine access, cropland }\end{array}$ & Year-round use, in the vicinity of settlements, mown \\
\hline Other & $\begin{array}{l}\text { Overgrown meadows, overgrown alpine } \\
\text { pasture, shrubs, bushes, settlement, rock }\end{array}$ & Vegetation height $<3 \mathrm{~m}$, vegetation density $>50 \%$ \\
\hline
\end{tabular}

in land use between 1985 and 1997. The spatial distribution of future landscape composition under the business-as-usual scenario would closely resemble the 1997 landscape (Figure 2). Forests would prevail in mountainous areas (Northern, Central, Southern Alps, Figure 1), whereas the valleys and the Plateau would remain intensively managed (agriculture). Extensive agricultural management under this scenario continues in the Jura mountains, Northern pre-Alps, and at higher elevations of the Central and Southern Alps (Figure 2). The overall proportion of forested areas would increase slightly in comparison to 1997 $(+0.6 \%)$, whereas intensively and extensively managed open-land would generally decrease $(-0.01$ and $-0.55 \%$, respectively) (Figure 3$)$.

The liberalization scenario assumes no public support to conservation or public support to agricultural production. This indicates full reforestation potential for open-land areas with two exceptions: low reforestation potential is assumed in the lowlands and in important mountain tourist resorts as these areas are likely to remain settled and managed due to higher infrastructure availability and

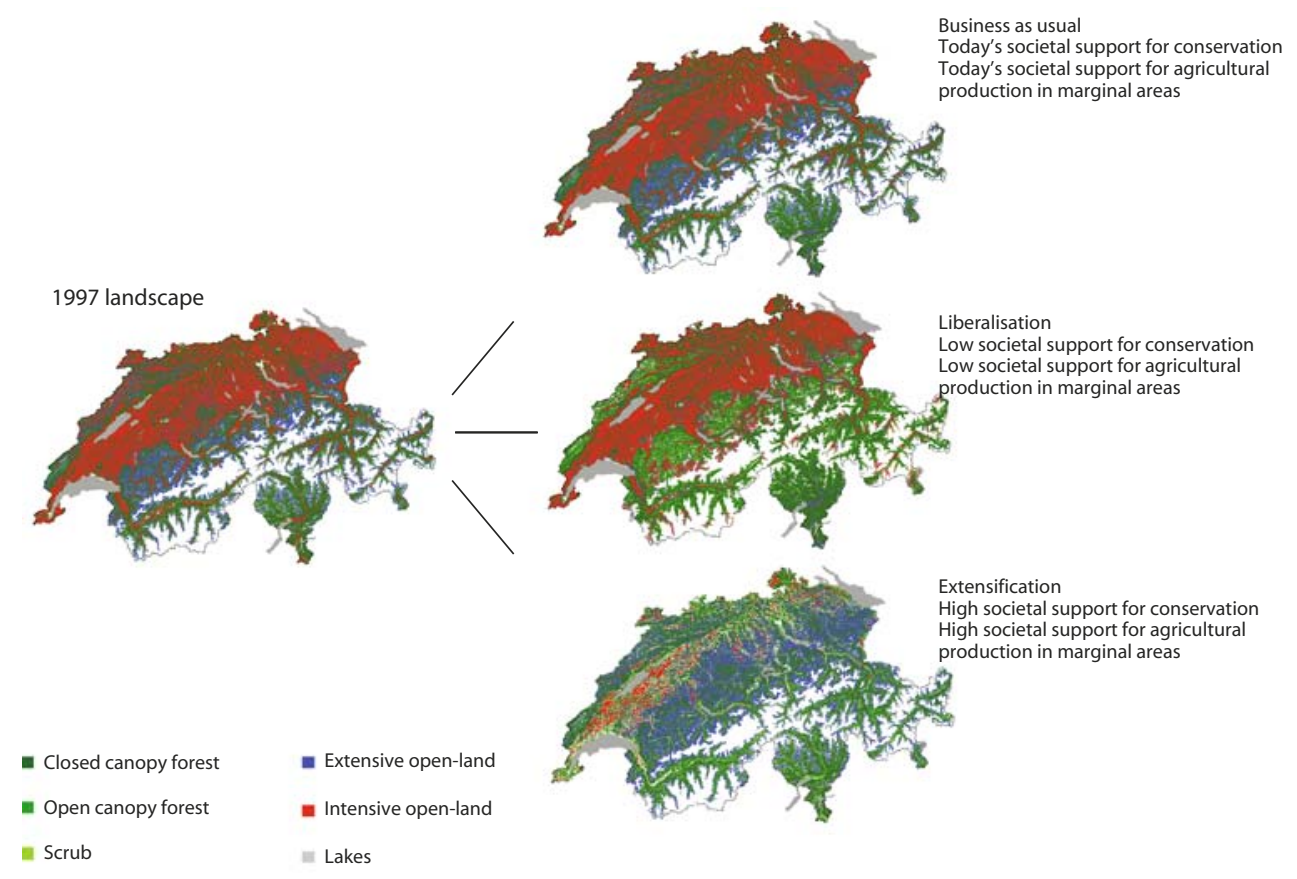

Figure 2. Scenarios of land-use change developed in an EUresearch program (BioScene) (modified from Bolliger and others 2007). 


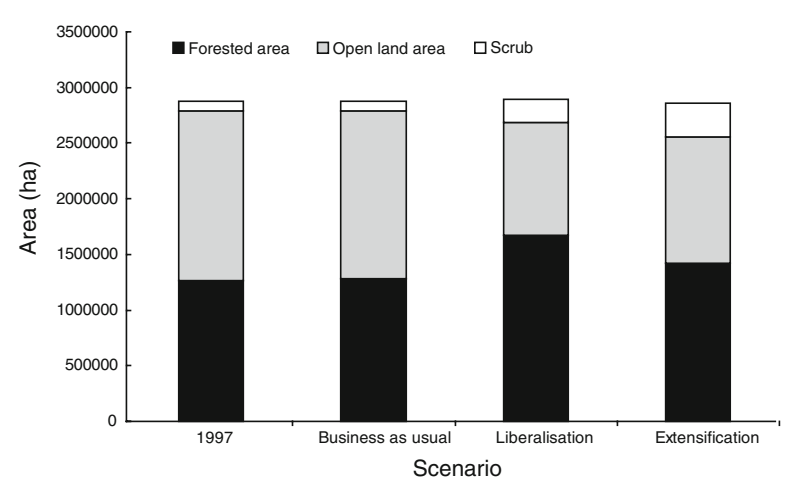

Figure 3. Distribution of areas for forest, scrub (not considered in the analysis), and open-land (intensively and extensively managed) under three scenarios of landuse change.

easy accessibility. The liberalization scenario suggests a spatial segregation between the mountains and the lowlands: intensive agricultural land use would prevail in the lowlands (Plateau) and valley bottoms of the Central and Northern part of the Alps, whereas the higher elevations (Northern, Central, Southern Alps) would become forested, primarily reducing areas of non-intensively used open land (Figure 2). This indicates that the proportion of open-land would decrease in favor of forests (Figures 2 and 3). The liberalization scenario suggests an increase in forest area by $15 \%$ and a corresponding decrease in agricultural land by $15.8 \%$ (extensive: $-14.5 \%$; intensive: $-1.3 \%$ ) (Figure 3).

The extensification scenario assumes no public support to current intensive agricultural production in favor of more conservation-oriented management. This would result in gains of extensively managed open-land (Figure 2). Parts of intensively used agricultural areas in the lowlands would become extensively managed $(+10.9 \%)$, whereas intensively managed open-land would decrease $(-24.6 \%)$. However, general depopulation tendencies observed for mountainous areas are assumed to persist, even though those areas would become heavily subsidized. This would lead to slight reforestation tendencies $(+5.8 \%)$ and scrub $(+7.9 \%)$ (Bolliger and others 2007).

\section{Estimating Current C Stocks in Switzerland}

Forest C Stocks. We considered forest biomass and forest soils to asses total forest $\mathrm{C}$ stocks. The $\mathrm{C}$ estimations were calculated separately for five productivity regions (Figure 1) and two altitudinal strata (below and above $1000 \mathrm{~m}$ asl).
Forest Biomass C Stock and Stock Changes. Estimations of $C$ stocks in forest biomass were based on the Swiss National Forest Inventory (Brassel and Brändli 1999). The estimations were performed in three steps, following the FAO guidelines for country reporting (FAO 2004). First, the growing stock (wood volume) was estimated using sample plots for the land-use class "forest" (Table 2). Second, growing stocks were converted to biomass through multiplication with wood density (Vorreiter 1949) and a specific biomass expansion factor for different productivity regions and elevation strata (Thürig and others 2005). The factors were aggregated to match the elevation strata below and above $1000 \mathrm{~m}$ asl. Third, the total tree biomass per ha was converted into biomass $\mathrm{C}$ ha ${ }^{-1}$ by applying a constant $C$ content of $50 \%$ (IPCC 2003).

Change in $\mathrm{C}$ stocks on the currently forested land-the C sink-was calculated from the increase in biomass $\mathrm{C}$ of the National Forest Inventories between 1985 and 1995 (Brassel and Brändli 1999). As with C stocks, the changes in biomass $C$ were estimated from growing stocks using wood densities, specific biomass expansion factors, and a constant C content.

Forest Soil C Stock. Our calculation of regional mean soil organic C (SOC) stocks in forest soils relied on data of 264 soil profiles. Forest soil data representative for Swiss forests in terms of climate and forest type were used (Perruchoud and others 2000). An additional 96 forest soil profiles were derived from regional soil surveys (VanMechelen and others 1997).

Concentrations of soil $\mathrm{C}$ were determined for all profiles according to Perruchoud and others (2000). Soil densities were measured in 105 soil profiles using soil cylinders and by replacing soil volume with sand in stony soils. Densities of the other soil profiles were estimated by regressing measured densities with SOC concentrations (Perruchoud and others 2000). Soil organic masses were measured with a $20 \times 20 \mathrm{~cm}$ frame in 50 profiles. The estimated densities for L, F, and $\mathrm{H}$ horizons were then used to calculate the soil organic masses of the other profiles based on their thicknesses. Subsequently, the SOC stock size (in $\left[\mathrm{tC} \mathrm{ha}{ }^{-1}\right]$ ) was determined by

$$
\operatorname{SOC}_{d_{\mathrm{z}}}=\sum_{i}^{d_{z}} \rho_{\mathrm{FE}} \times\left(1-\frac{\delta_{i, 2 m m}}{100}\right) \times d_{i} \times C_{i}
$$

where $\rho_{\mathrm{FE}}$ denotes the fine earth density of layer $i$ in $\mathrm{kg} \mathrm{dm}^{-3}, d_{i}$ denotes the thickness of layer $i$ in $\mathrm{dm}, C_{i}$ is the $\mathrm{C}$ stock in $\mathrm{g} \mathrm{kg}^{-1}$, and $\sum_{i}^{d_{\mathrm{z}}}$ integrates between the soil surface and the soil depth $d_{\mathrm{z}}$. SOC 
estimates were calculated to maximum soil depth with detectable $\mathrm{C}$ stocks. The mean depth of forest soils in Perruchoud and others (2000) is $61 \mathrm{~cm}$.

Agroecosystem C Stocks. Agricultural land at an altitude less than $1000 \mathrm{~m}$ asl is generally intensively used, whereas areas at elevations higher than $1000 \mathrm{~m}$ asl are largely extensively managed, owing to their relatively marginal, unproductive qualities. Our C estimations for intensively managed agricultural land relied on individual estimations for arable land $(10.5 \%$ of the total area), temporary $(4.2 \%)$, and favorable grasslands $(18.6 \%)$ (Leifeld and others 2005; Table 3).

C stocks in agricultural soils were taken from Leifeld and others (2005). Calculation of the C stock was performed according to equation (1) but to a maximum soil depth of $1 \mathrm{~m}$. The $\mathrm{C}$ stock estimates in agricultural soils of Leifeld and others (2005) included development of pedotransfer functions for SOC and bulk density based on 544 soil profiles from Swiss agricultural soil surveys with elevation, clay content, stone content, and land use as predictors. Clay contents explained $61-71 \%$ of the variation in $\mathrm{C}$ concentrations for arable land and temporary grasslands, whereas elevation was a more important predictor for $\mathrm{C}$ in permanent grasslands $\left(R^{2}=0.55\right)$ (Leifeld and others 2003, 2005). Stone content was particularly important for carbon storage at higher elevations where stones limit the available soil volume. Sixty-nine percent of the variation in soil bulk densities could be explained by $\mathrm{C}$ concentrations. Errors in SOC stocks as derived from both $\mathrm{C}$ concentrations and bulk densities were calculated by error propagation (Leifeld and others 2003, 2005). Upscaling was done by assigning $\mathrm{C}$ stocks to parcels of identical soil unit, topography, and land-use type and multiplication with the respective area (Leifeld and others $2003,2005)$. The mean depth of all agricultural soils is $66 \mathrm{~cm}$ (J. Leifeld, personal communication).

C stocks for agricultural biomass are negligibly small, annually harvested and thus not considered here. Because organic soils cannot be assessed spatially explicitly (Leifeld and others 2005), they are not included in this analysis. Rather, the proportion of organic soils is assumed to remain constant over time, independent of land use and land-use change.

\section{Uncertainty Assessment}

The input values for our overall C stock estimations originate from different data sources and models. Such a highly aggregated compilation of data material is associated with uncertainty. Our uncertainty assessment relied on the maximum differences in C stocks between the three scenarios and the 1997 landscape for each land-use type (forest biomass, forest soil, extensive and intensive agriculture). The maximum differences ( $\mathrm{MtC}$ ) were then expressed as percent of the $1997 \mathrm{C}$ stocks. This percentage represents the maximum range of uncertainty with which the C stock estimations in 1997 may be associated with if the scenarios should have an effect on the overall $\mathrm{C}$ stock estimations.

\section{Spatial Assessment of C Stocks Under Scenarios of Land-Use Change}

The effects of the different land-use scenarios on C stocks in Switzerland were assessed by multiplying

Table 3. Overall C Stocks for Switzerland for the 1997 Landscape

\begin{tabular}{|c|c|c|c|c|}
\hline Land-use type & Area (1000 ha) & Area $(\%)$ & $\begin{array}{l}\text { tC } \text { ha }^{-1} \\
\text { ( } \pm \text { standard } \\
\text { error) }\end{array}$ & $\begin{array}{l}\text { MtC } \\
\text { ( } \pm \text { standard } \\
\text { error) }\end{array}$ \\
\hline \multicolumn{5}{|l|}{ Forest } \\
\hline (a) Biomass & 1265.9 & 45.4 & $116.8 \pm 1.5$ & $147.9 \pm 1.9$ \\
\hline (b) Soil & & & $118.6 \pm 5.4$ & $150 \pm 6.8$ \\
\hline Total (forest) & 1265.9 & 45.4 & & $297.9 \pm 8.7$ \\
\hline Scrub (not considered in analysis) & 90.6 & 3.2 & - & - \\
\hline Total extensively used open land $(>1000 \mathrm{~m} \text { asl })^{1}$ & 596.3 & 21.4 & $62.9 \pm 3.5$ & $37.5 \pm 4.4$ \\
\hline \multicolumn{5}{|l|}{ Intensively used open-land $(<1000 \mathrm{~m} \text { asl })^{1}$} \\
\hline (a) Arable land & 293.9 & 10.5 & $90.4 \pm 2.3$ & $26.57 \pm 2.9$ \\
\hline (b) Temporary grassland & 115.9 & 4.2 & $117.4 \pm 1.3$ & $13.61 \pm 1.7$ \\
\hline (c) Favorable grassland & 518.9 & 18.6 & $93.3 \pm 4.4$ & $48.41 \pm 5.6$ \\
\hline Total (intensively used open land) & 928.8 & 33.3 & & $88.6 \pm 10.2$ \\
\hline Total (forest, intensively, extensively used open land) & 2791.0 & 100 & & $424 \pm 23.3$ \\
\hline
\end{tabular}


current $\mathrm{C}$ stock estimates ( $\mathrm{tC} \mathrm{ha}^{-1}$ ) with the areas (ha) of the respective land uses (forest biomass, forest soil, intensively and extensively managed open land) in 1997 and under the three scenarios of land-use change. The $\mathrm{C}$ stock assessment is thus a direct function of the areas covered by the respective land-use types and relies on the assumption that the scenarios and the corresponding $\mathrm{C}$ stocks are fully developed following land-use change.

The forest area (1.2 Mha) was derived from the National Forest Inventory of Switzerland (Brassel and Brändli 1999) and corresponds to the areas classified as forests in the land-use statistics data used for land-use change scenario development. The estimation of the agroecosystem areas amounts to approximately 1.3 Mha $(0.8$ Mha for intensively and 0.5 Mha for extensively used agricultural land) following the land-use statistics data used to perform the land-use change scenarios. Leifeld and others (2005), however, considered additional data sources and came up with a more precise estimation of the total agricultural area, amounting to roughly $1.5 \mathrm{Mha}$, whereof 0.9 Mha are intensively and 0.6 Mha are extensively managed (Table 3). In comparison to the land-use statistics that form the baseline data for the land-use change scenario development, Leifeld's and others (2005) estimates are thus about $11 \%$ higher for intensively and $17 \%$ higher for extensively managed land. We applied these proportions to the land-use change scenarios.

We mapped the spatial distribution of $\mathrm{C}$ gains and losses by summing the amount of $\mathrm{C}$ per pixel $\left(\mathrm{tC} \mathrm{ha}^{-1}\right)$ using forest soil and forest biomass values, stratified according to productivity region and altitude. For open-land C, only two strata were available: above $1000 \mathrm{~m}$ asl, agricultural areas are extensively used; at elevations lower than $1000 \mathrm{~m}$ asl, agricultural areas are primarily intensively used which is expressed as the weighted mean of arable land, temporary, and favorable grassland (91 tC $\left.\mathrm{ha}^{-1}\right)$.

\section{RESUltS}

\section{Stocks and Sinks in Switzerland}

The overall C stock for Switzerland in 1997 amounts on average to $424 \mathrm{MtC}$ (Figure 4, Table 3). C stocks for forest soils are largest, but differ only by $1.4 \%$ from forest biomass (Figure 4, Table 3). Agricultural soils exhibit on average $27 \%$ lower C stocks per area in comparison with forest soils (Figure 4, Table 3) associated with a lower residue return and likely with a tillage-induced accelerated turnover (FAL 2001). Soil C stocks for intensively used agricultural land are $57.7 \%$ greater compared to extensively

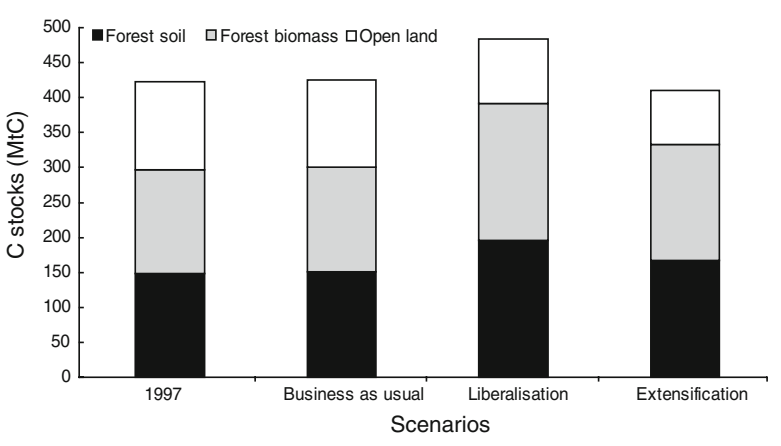

Figure 4. Distribution of C stocks (agroecosystem and forest biomass, forest soils) under three scenarios of landuse change.

used agricultural land (Figure 4, Table 3). This is due to the fact that extensively used agricultural lands are mainly found at elevations higher than $1000 \mathrm{~m}$ asl which include unfavorable permanent grasslands. These grasslands are characterized by shallower soil profiles and higher stone contents which, in combination with climate-induced lower productivity, cause a smaller $\mathrm{C}$ stock. The largest proportion of intensively used open-land is made up by favorable grasslands $(54.6 \%)$, followed by arable land (30\%) and temporary grassland (15.4\%) (Figure 4, Table 3).

Swiss forests are currently C sinks because regrowth exceeds wood harvest (Table 4). The National Forest Inventories in 1985 and 1995 indicate that mean annual stem wood production is approximately $9 \mathrm{Mm}^{3} \mathrm{y}^{-1}$, but mean annual harvest is only 6.3 $\mathrm{Mm}^{3} \mathrm{y}^{-1}$ (Brassel and Brändli 1999). Converting this net increment into $\mathrm{C}$ sequestered by forest biomass yields $0.8-0.9 \mathrm{MtC} \mathrm{y}^{-1}$ or on an area basis $0.7-0.8 \mathrm{tC}^{\text {ha } \mathrm{y}^{-1}}$, which is slightly higher than the increasing $\mathrm{C}$ stocks across European forests

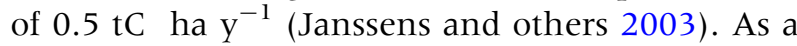
result of the increasing forest biomass and litter production, modeling studies suggest that Swiss forest soils are currently $\mathrm{C}$ sinks, but uncertainties are large with values ranging from 0.1 to $0.3 \mathrm{tC}$ ha ${ }^{-1} \mathrm{y}^{-1}$ (Perruchoud and others 1999; Liski and others 2002; Schmid and others 2006). Overall, current C sinks in Swiss forests amount to roughly 1 MtC $\mathrm{y}^{-1}$ (Table 4; Hagedorn 2005). Agriculture is a net source of greenhouse gases with an emission of $1.4 \mathrm{Mt} \mathrm{CO}_{2}-\mathrm{C}$ equivalents in 2004. The mean Swiss LULUCF sink between 1990 and 2005 was $0.36 \mathrm{MtC}^{-1}$. This sink is composed of a net forest uptake of $0.77 \mathrm{MtC} \mathrm{y}^{-1}$, which is partially offset by

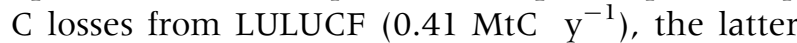
including $0.17 \mathrm{MtC}$ from drainage of organic soils plus contributions from $\mathrm{C}$ loss mainly due to conversion to settlement. 
Table 4. C Sinks in Swiss Ecosystems Under Different Land-Use Change Scenarios

\begin{tabular}{|c|c|c|c|}
\hline Land-use change scenario & & $\operatorname{MtC} y^{-1}$ & tC ha-1 $y^{-1}$ \\
\hline Business-as-usual & $\begin{array}{l}\text { Forest biomass } \\
\text { Soils }^{2}\end{array}$ & $\begin{array}{l}<0.05 \\
<0.05\end{array}$ & $\begin{array}{l}<0.05 \\
<0.05\end{array}$ \\
\hline Extensification & $\begin{array}{l}\text { Forest biomass }{ }^{1} \\
\text { Soils }^{2}\end{array}$ & $\begin{aligned} & 0.5 \\
< & 0.05\end{aligned}$ & $\begin{array}{c}0.4 \\
<0.05\end{array}$ \\
\hline Liberalization & $\begin{array}{l}\text { Forest biomass } \\
\text { Soils }^{2}\end{array}$ & $\begin{array}{l}0.5 \\
0.2-0.4\end{array}$ & $\begin{array}{l}0.4 \\
0.15-0.25\end{array}$ \\
\hline Current C sink & $\begin{array}{l}\text { Forest biomass } \\
\text { Soils }^{3}\end{array}$ & $\begin{array}{l}0.8-0.9 \\
0.1-0.3\end{array}$ & $\begin{array}{l}0.7-0.8 \\
0.08-0.25\end{array}$ \\
\hline
\end{tabular}

\section{Effects of Land-Use Change Scenarios on C Stocks}

Under the business-as-usual scenario, only a marginal overall C-stock increase of $0.5 \%(+2.3 \mathrm{MtC})$ would be expected after an estimated build-up time of 30 years (Figure 4). A larger increase in C stocks of $12.7 \%$ could be observed under the liberalization scenario (+62 MtC) after an estimated buildup time of 100 years. Roughly $74 \%$ (95 MtC) of this increase may be attributed to greater $\mathrm{C}$ stocks in forest soils and biomass, whereas $\mathrm{C}$ stocks in agricultural land may decrease by $26 \%$ ( $33.3 \mathrm{MtC}$ ). The extensification scenario results in a $2.9 \%$ overall loss in C stocks $(-12.2 \mathrm{MtC})$ compared to 1997 after an estimated build-up time of 80 years (Figure 4). In this scenario, C gains through an increase in forests $(+36.5 \mathrm{MtC})$ are balanced out by expected $\mathrm{C}$ losses from agricultural soils by a more extensive open-land management $(-48.6 \mathrm{MtC})$.

For agricultural open-land, C stocks are expected to decrease $1.3 \%(-1.6 \mathrm{MtC})$ under the businessas-usual scenario compared to the 1997 landscape (Figure 5). C-stock losses in intensively and extensively managed open-land range below 1.5\% (Figure 5). Under the liberalization scenario, however, an overall decrease of open-land C stocks of $-33.3 \mathrm{MtC}(-36 \%)$ would be expected due to strong reforestation (Figure 5). Extensively used agricultural land would decrease $21 \%$ $(-29.6 \mathrm{MtC})$, whereas C stock losses for intensively managed land are expected to amount only to $4.2 \%$ $(-3.8 \mathrm{MtC})$ under liberalization (Figure 5). Under the extensification scenario, the overall open-land C stock would decrease by $38.5 \% \quad(-48.6 \mathrm{MtC})$ (Figure 5). This decrease is attributed to the fact that intensively managed open land is converted into extensively used open land, which stores about $31 \%$ less C (Figure 5, Table 3).

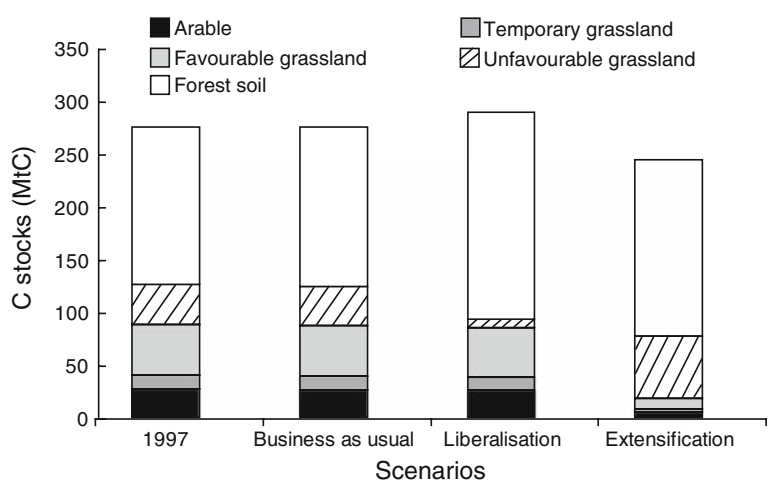

Figure 5. Distribution of agroecosystem soil C stocks for various management schemes under scenarios of landuse change in comparison with forest soil stocks.

\section{Uncertainty Assessment}

The uncertainty assessment indicates that the maximum difference in $\mathrm{C}$ stocks for forest biomass and soil is $47 \mathrm{MtC}$ between the liberalization scenario and the 1997 reference landscape. This is $32 \%$ of the estimated value for 1997 . In comparison, the observed uncertainty for forests is six times lower than the effects that the liberalization scenario suggests (Table 3). For extensively used agricultural soils, the maximum difference in $\mathrm{C}$ stocks is between the extensification and the liberalization scenario and amounts to $51.8 \mathrm{MtC}$. This is $38 \%$ more than the $\mathrm{C}$ stock estimation of 37.5 MtC for extensively used open-land in 1997 and exceeds roughly 12 times the currently observed uncertainty for extensively used agricultural soils (Table 3). For intensively managed openland, the maximum difference in $\mathrm{C}$ stocks is $67 \mathrm{MtC}$ between the liberalization and the extensification scenario. This is $58 \%$ of the estimated C stocks for 1997 and exceeds the observed 
uncertainty estimated for current $\mathrm{C}$ stocks in intensively managed open lands by roughly six times (Table 3).

To summarize, the observed uncertainty associated with the 1997 estimations is lower than or ranges around $10 \%$ (Table 3). This is 6-12 times less than what the liberalization and the extensification scenarios suggest. Thus, results from the uncertainty assessment indicate that the scenarioderived changes in $\mathrm{C}$ stocks for liberalization and extensification are likely to have a major impact on the overall C stock in Switzerland, whereas the business-as-usual scenario would cause only marginal changes.

\section{Spatial Distribution of C-Stock Gains and Losses}

C-stock changes are likely to be spatially segregated across Switzerland for the liberalization (Figure 6A)

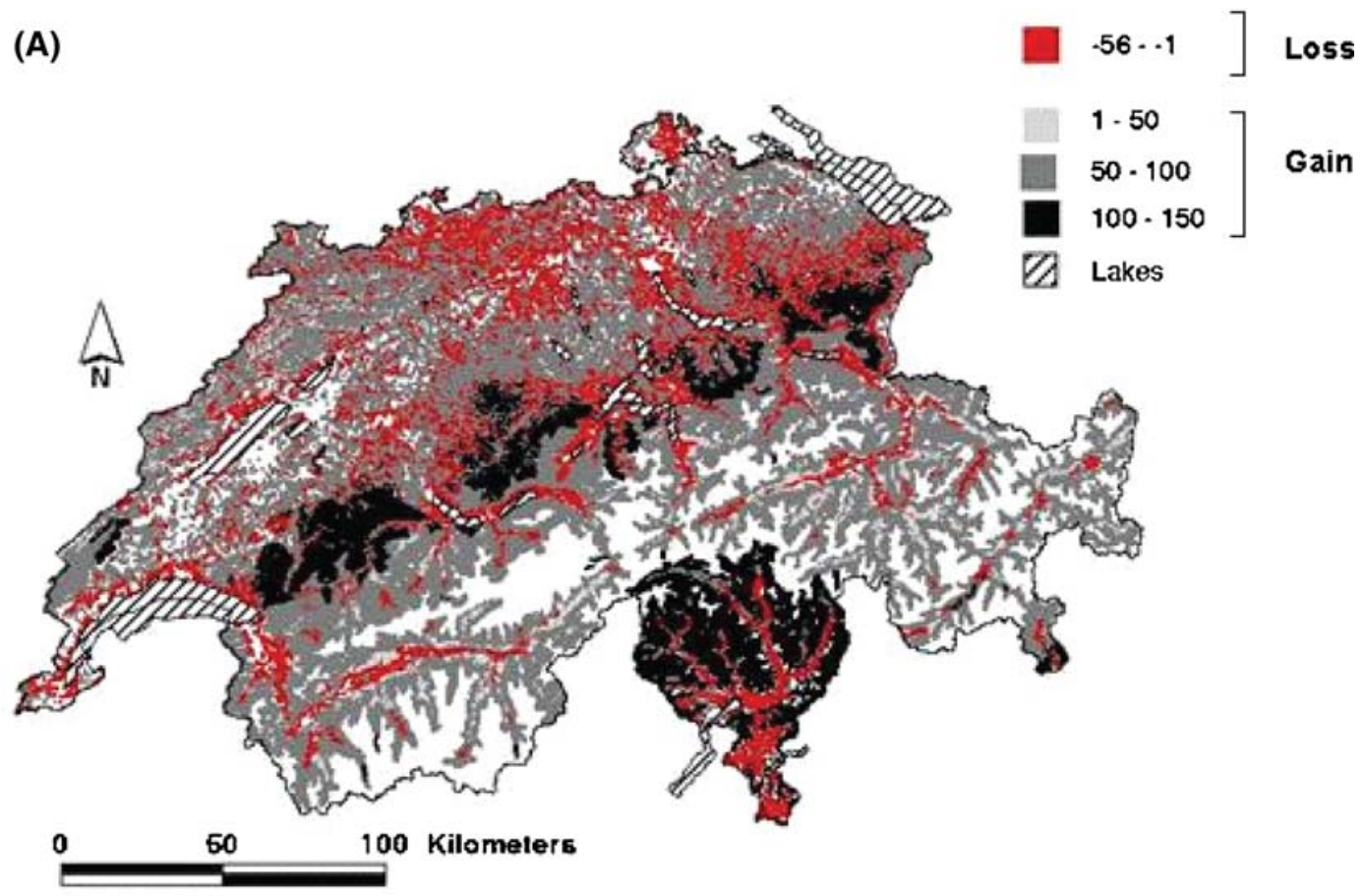

(B)

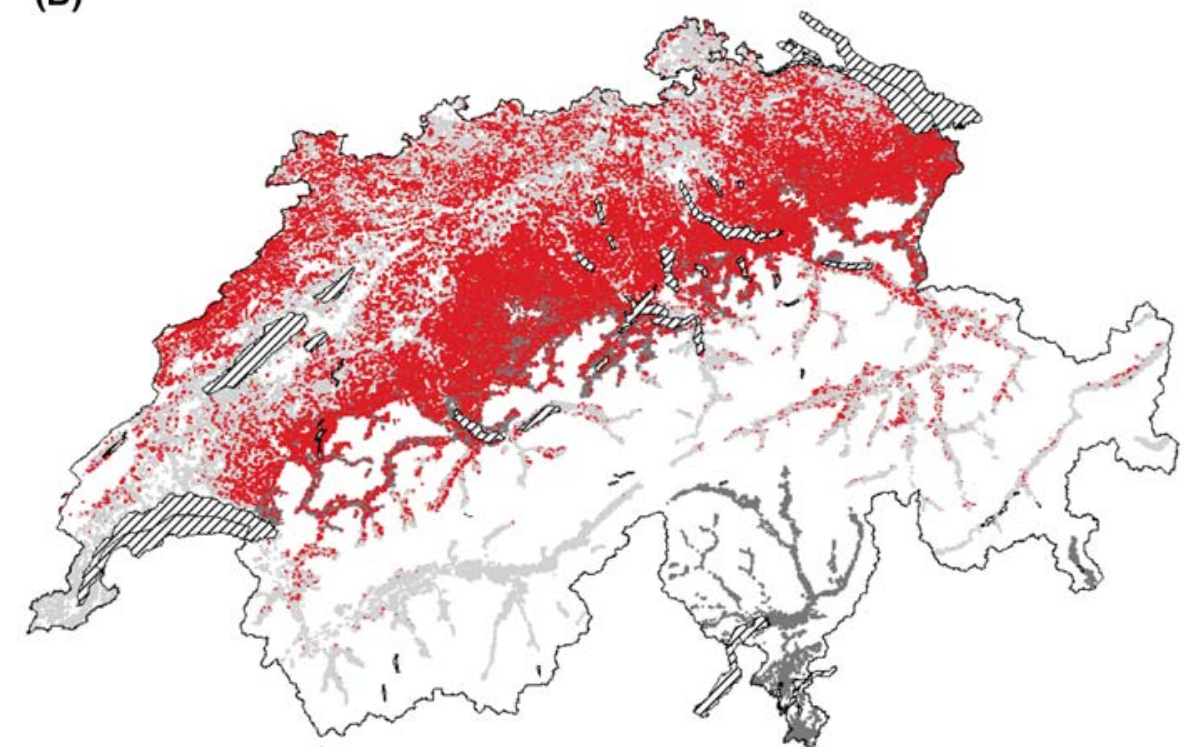

Figure 6. C gains and losses ( $\mathrm{tC} \mathrm{ha}^{-1}$ ) (A) of the liberalization scenario versus the 1997 landscape and (B) of the extensification scenario versus the 1997 landscape. 
and the extensification scenario (Figure 6B). Under liberalization, major C-stock gains are observed in mountainous regions, especially for the Northern and the Southern Alps with C-stock increases of up to $134 \mathrm{tC} \mathrm{ha}^{-1}$ (Figure 6A). Losses under liberalization encompass major valley bottoms in the Alps, some areas in the Northern Alps and the northern Jura mountains. These losses occur on formerly intensively managed open-land which is being extensified under liberalization. C-stock gains under the extensification scenario are observed for mountainous and hilly areas including major valleys in the Alps (Figure 6B), particularly the Southern Alps. Losses are likely to occur on the Plateau where large proportions of intensively used agricultural land are converted into extensively used open land (Figure 6B).

\section{Discussion}

\section{Approach}

The Kyoto-Protocol promotes management activities to increase $\mathrm{C}$ stocks in ecosystems, but land use is and will be largely driven by other socioeconomic constraints. We chose a scenario-based assessment to estimate how general socio-economic trends may affect future $\mathrm{C}$ stock changes at a national level. To do so, we quantified changes in area of major land-use types under varying socio-economic conditions by combining scenariobased, spatial modeling with estimations of $\mathrm{C}$ stocks for forest biomass, forest soils, and agricultural open-land. These changes were subsequently translated into potential changes of terrestrial C stocks. The scenarios of land-use change presented here describe a broad range of potential pathways which could enhance policy discussions that aim to assess future demands and productivity across the landscape, as well as the potential of managed land to act as a $\mathrm{C}$ sink. The moderate business-as-usual scenario is contrasted by a more extreme liberalization and an extensification scenario. The liberalization scenario would lead to a $24.3 \%$ increase in forest cover, mainly in mountainous areas after a build-up time which we estimate to be 100 years. Agriculture in the lowlands would intensify due to favorable socio-economic, topographic and infrastructural conditions which foster agricultural management, whereas mountainous regions would become increasingly forested. Extensification would mean a $37 \%$ increase of currently extensively used open land and an $80 \%$ decrease of currently intensively used open-land.
Results from the uncertainty assessment indicate that land-use change as suggested by the liberalization and the extensification scenarios is likely to have a major impact on $\mathrm{C}$ stocks and thus C sequestration in Switzerland. The largest change would be observed under liberalization which would lead to a gain of $62 \mathrm{MtC}$ due to an increase in forested area at higher elevations and to a more intensive management of agricultural land in the lowlands. Current forest inventory data show that $\mathrm{C}$ stocks in forests are increasing by $1 \mathrm{MtC} \mathrm{y}^{-1}$ (Table 4). Assuming a build-up time of 100 years for the liberalization scenario would yield a maximal C sink of 1.6-2 MtC $\mathrm{y}^{-1}$ in Switzerland. This might suffice to fully compensate the amount of agricultural greenhouse gases (2004: $1.4 \mathrm{Mt} \mathrm{CO}_{2}-\mathrm{C}$ equivalents). However, 1.6-2 $\mathrm{MtC} \mathrm{y}^{-1}$ corresponds only to $11-13 \%$ of the currently emitted greenhouse gases, indicating that even the largest of the expected terrestrial C sinks per year would be small in comparison with current anthropogenic greenhouse gas emissions.

Our approach leaves a variety of caveats. First, our assessment is based on a compilation of various types of data from national-scale estimation of overall C stocks. Second, the land-use effects on soil C inferred from current stocks might be partly related to inherent differences in soil $\mathrm{C}$ stocks among soils with historically different management. Thus, the C-stock data originate from different sources, some may not be fully compatible, and some may measure past management schemes rather than natural variation. The information employed in this study originates from empirical data collected with representative sampling strategies accounting for geographical and thus, implicitly, also for management variation (forest biomass: National Forest Inventory (Brassel and Brändli 1999); forest soils: (Perruchoud and others (2000), and up-scaled data for soil $\mathrm{C}$ estimations of open-lands: Leifeld and others (2005). Although up-scaled data do not account for spatial variability to the same degree as empirical data, our overall soil-C assessment relies on several hundred soil profiles and thus mirrors major spatial characteristics at the landscape scale rather than local-scale details. In addition, results from the uncertainty assessment as performed in this study indicate that a relatively large error range of $32 \%$ is likely to cause effects on overall C stocks under the liberalization and the extensification scenario.

Third, the dynamics of change and thus the $\mathrm{C}$ sequestration within one land-use form (particularly in forests) cannot be accounted for. The spatially explicit data on which the scenarios rely 
represent information on two discrete time steps, and thus do not provide temporally continuous information. Implicitly, however, build-up times for the scenarios can be estimated as 30 years for the business-as-usual scenario, 80 years for the extensification scenario, and 100 years for the liberalization scenario. Our static approach likely underestimates potential $\mathrm{C}$ accumulation in forests under all three scenarios because C stocks of Swiss forests are currently increasing (Brassel and Brändli 1999; Hagedorn 2005). We presume, however, that the net increment in C stocks in Swiss forests will decline in the near future because the use and processing of wood is promoted by Swiss Forestry agencies, new sawmills are built and the demand for wood chips for heating is currently increasing. In addition, Swiss forests already have $C$ stocks that are among the highest in Europe $\left(117 \mathrm{tC} \mathrm{ha}^{-1}\right.$; $350 \mathrm{~m}^{3} \mathrm{ha}^{-1}$ ) (Liski and others 2002). Net growth rates are thus close to 'saturation'. Additionally, our assumption of declining $\mathrm{C}$ sinks per area forest is supported by the modeling study of Schmid and others (2006), which suggests that under 'minimum' forest management, biomass $\mathrm{C}$ stocks will reach a plateau within the next $60-80$ years.

\section{Effects of Land-Use Change on C Stocks: Agroecosystem and Forest Soils}

The conversion of cropland to forest is likely to increase soil organic C stocks (SOC) (Guo and Gifford 2002). It is not clear, however, how reforestation on former pastures, the most significant agricultural land use and the land use with the highest likelihood of change, affects SOC stocks (Conant and others 2001; Guo and Gifford 2002; Jandl and others 2007). For instance, Richter and others (1999) and Vesterdal and others (2002) observed along chronosequences from arable land to forest floors that SOC stocks increased in the forest floor, but decreased in the mineral horizons, resulting in relatively small net effects. Systematic comparisons for forest and agricultural soils in alpine regions are not available. Our data compilation suggests that forest soils store $35 \mathrm{tC} \mathrm{ha} \mathrm{ha}^{-1}$ more $\mathrm{C}$ than grassland soils. Because forests are usually on marginal land with smaller inherent SOC stocks (as it is the case for agricultural land; Table 3), it seems likely that reforestation indeed increases C stocks. Our assessment suggests also that extensification of currently intensively used open-land leads to decreasing C stocks. Again, this conclusion is based on the current $\mathrm{C}$ stocks in Swiss agricultural soils, which are greater in intensively managed soils $\left(+28\right.$ tC ha $\left.^{-1}\right)$. Intensively managed land is usually on more favorable sites with inherently greater C stocks (Leifeld and others 2005). Consequently, we might have overestimated the potential SOC losses through extensification. We suggest that a $31 \%$ greater $\mathrm{C}$ stock in intensively managed soils is reasonable because (a) of their higher productivity, and (b) for sites with similar texture and climate approximately one standard deviation of SOC stocks is observed under permanent grassland in the Swiss Central Plateau (Leifeld and others 2005). This result agrees with a number of case studies (Conant and others 2001; Guo and Gifford 2002; Jandl and others 2007) and is confirmed by recent eddy-covariance measurements of a meadow under intensive versus extensive use in the Swiss Central Plateau (Amman and others 2007). Although intensive agriculture likely leads to $\mathrm{C}$ gains in soils, it could increase emissions of other greenhouse gases such as $\mathrm{N}_{2} \mathrm{O}$ and methane due to larger animal herds and the use of fertilizers.

\section{Rates of C-Stock Changes}

Our static assessment represents an estimate of potential effects on C stocks. We can only speculate on the rates of change and the $\mathrm{C}$ source-sink dynamics that are most relevant for the Swiss C budget. For reforestation, the most significant landuse change, the rates of change in biomass may be estimated by assuming a mean stand age of 100 years as a likely build-up time for Swiss forests (National Forest Inventory, Brassel and Brändli 1999). In this case, the liberalization scenario would lead to a C-stock increase by approximately $0.5 \mathrm{MtC}$ per year (47 MtC/100 years) in forest biomass (Table 4), which corresponds to $3 \%$ of the gross annual greenhouse gas emissions of 1990. This assumption is a maximal C-stock change rate because the increase in forest area is a slow process.

Rates of changes in soil C stocks contain much greater uncertainties than those of biomass as they depend on regional variation in climate, geology, mineralogy, hydrology, and the magnitude of difference between current and expected C stocks. For the conversion of agricultural open-land to forest, we assume that the major SOC stock changes take as much time as required to fully establish a mature forest. This corresponds to the time until C stocks in soil organic layers in forests reach a steady state (80-100 years, Böttcher and Springob 2001). Changes in management intensity of agricultural land, for example, fertilization, are also expected to take decades until new steady-states are reached. For example, the Rothamsted Broadbalk continu- 
ous wheat experiment shows continuously increasing C stocks since 1860 under steady manure applications, indicating that even 100 years may be too short to balance inputs and outputs (Jenkinson 1991). Assuming that SOC stocks would change during 50-100 years shows that the $\mathrm{C}$ sink in soils would amount to $0.2-0.4{\mathrm{MtC} \mathrm{y}^{-1}}^{-1}$ at maximum under the liberalization scenario which represents the greatest expected changes in land use (Table 4). For the business-as-usual and the extensification scenario with an estimated build-up time of 30 years, the $\mathrm{C}$ sink in soils would be below $0.05 \mathrm{MtC} \mathrm{y}^{-1}$. In combination with the expected $\mathrm{C}$ sink under liberalization, the total $\mathrm{C}$ sink in Switzerland due to land-use changes would sum to $0.7-0.9 \mathrm{MtC} \mathrm{y}^{-1}$ (69 MtC/100 years), which corresponds to a mere $5-6 \%$ of the current anthropogenic greenhouse gas emissions.

\section{ACKNOWLEDGEMENTS}

The authors thank Peter Pearman for carefully commenting and editing the article. Two anonymous reviewers strongly improved the manuscript with helpful suggestions and comments. This research was supported by the BioScene project funded by the European Union (EVK2-2001-00354).

\section{REFERENCES}

Amman C, Flechard C, Leifeld J, Neftel A, Fuhrer J. 2007. The carbon budget of newly established temperate grassland depends on management intensity. Agric Ecosyst Environ 121:5-20.

Bätzig W. 1996. Landwirtschaft im Alpenraum unverzichtbar, aber zukunftslos? Eine alpenweite Bilanz der aktuellen Probleme und der möglichen Lösungen. In: Bätzig W, Ed. Landwirtschaft im Alpenraum - unverzichtbar, aber zukunftslos? Europäische Akademie Bozen, Fachbereich Alpine Umwelt. Wien: Blackwell. pp. 9-11.

BFS. 1979/85. Arealstatistik. Bundesamt für Statistik, Servicestelle GEOSTAT, CH-Neuchatel.

BFS. 1992/97. Arealstatistik. Bundesamt für Statistik, Servicestelle GEOSTAT, CH-Neuchatel.

Bolliger J, Kienast F, Soliva R, Rutherford GN. 2007. Spatial sensitivity of species habitat patterns to scenarios of land-use change (Switzerland). Landsc Ecol 22:773-89.

Böttcher J, Springob G. 2001. A carbon balance model for organic layers of acid forest soils. J Plant Nutr Soil Sci 164:399405.

Brassel P, Brändli UB. 1999. Schweizerisches Landesforstinventar. Ergebnisse der Zweitaufnahme 1993-1995. Birmensdorf, Eidgenössische Forschungsanstalt für Wald Schnee und Landschaft, Bern, Bundesamt für Umwelt, Wald und Landschaft.

Ciais P, Tans PP, Trolier M, White JWC, Francey RJ. 1995. A large northern hemisphere $\mathrm{CO}_{2}$ sink indicated by the ${ }^{13} \mathrm{C} /{ }^{12} \mathrm{C}$ ratio of atmospheric $\mathrm{CO}_{2}$. Science 269:1098-101.
Conant RT, Paustian K, Elliott ET. 2001. Grassland management and conversion into grassland: effects on soil carbon. Ecol Appl 11:343-55.

DeFries RS, Field CB, Fung I, Collatz GJ, Bounoua L. 1999. Combining satellite data and biogeochemical models to estimate global effects of human-induced land cover change on carbon emissions and primary productivity. Global Biogeochem Cycles 13:803-15.

Dirnböck T, Dullinger S, Grabherr G. 2003. A regional impact assessment of climate and land-use change on alpine vegetation. J Biogeogr 30:401-17.

Dullinger S, Dirnböck T, Grabherr G. 2003. Patterns of shrub invasion into high mountain grasslands of the Northern calcareous Alps, Austria. Arct Antarct Alp Res 35:434-41.

FAL. 2001. Grundlagen der Düngung im Futter- und Ackerbau. Eidgenössische Forschungsanstalt für Agrarökologie und Landbau, Zürich-Reckenholz.

FAO. 2003. The agricultural statistics of the Food and Agriculture Organisation of the United Nations.

FAO. 2004. Guidelines for Country Reporting to FRA 2005, working paper 82. Rome.

Guo LB, Gifford RM. 2002. Soil carbon stocks and land use change: a meta analysis. Glob Chang Biol 8:345-60.

Hagedorn F. 2005. Carbon stocks. Forest report 2005. Facts and figures about the condition of Swiss forests. SAEFL, Swiss Federal Institute WSL, Berne, Swiss Agency for the Environment, Forest and Landscape, Birmensdorf. pp. 36-9.

Houghton RA. 2003. Why are estimates of the terrestrial carbon balance so different? Glob Chang Biol 9:500-9.

IPCC. 2001. Climate change. The IPCC third assessment report. Cambridge and New York: Cambridge University Press.

IPCC. 2003. Good practice guidance for land use, land-use change and forestry. Intergovernmental Panel on Climate Change.

Jandl R, Lindner M, Bauwens B, Vesterdal L, Baritz R, Hagedorn F, Johnson D, Minkkinen K, Byrne K. 2007. How strongly can forest management influence soil carbon sequestration? Geoderma 137:253-68.

Janssens IA, Freibauer A, Ciais P, Smith P, Nabuurs G-J, Folberth G, Schlamadinger B, Hutjes RWA, Ceulemans R, Schulze E-D, Valentini R, Dolman AJ. 2003. Europe's terrestrial biosphere absorbs 7 to $12 \%$ of European antropogenic $\mathrm{CO}_{2}$ emissions. Science 300:1538-42.

Jenkinson DS. 1991. The Rothamsted long-term experiments-are they still of use. Agron J 83:2-10.

Kankaapää S, Carter TR. 2004. An overview of forest policies affecting land use in Europe. 706, The Finnish Environment, Finnish Environment Institute, Helsinki.

Labaune C, Magnin F. 2002. Pastoral management vs. land abandonment in Mediterranean uplands: impact on snail communities. Glob Ecol Biogeogr Lett 1 1:237-45.

Laiolo P, Dondero F, Ciliento E, Rolando A. 2004. Consequences of pastoral abandonment for the structure and diversity of the alpine avifauna. J Appl Ecol 41:294-304.

Leifeld J, Bassin S, Fuhrer J. 2003. Carbon stocks and carbon sequestration potentials in agricultural soils in Switzerland. Schriftenreihe der FAL, Reckenholz 44. pp. 120.

Leifeld J, Bassin S, Fuhrer J. 2005. Carbon stocks in Swiss agricultural soils predicted by land-use, soil characteristics, and altitude. Agric Ecosyst Environ 105:255-66. 
Lindborg R, Eriksson O. 2004. Historical landscape connectivity affects present plant species diversity. Ecology 85:1840-5.

Liski J, Perruchoud D, Karjalainen T. 2002. Increasing carbon stocks in the forest soils of western Europe. For Ecol Manage 169:159-75.

Maurer S, Weyand A, Fischer M, Stöcklin J. 2006. Old cultural traditions, in addition to land use and topography, are shaping plant diversity of grasslands in the Alps. Biol Conserv 130:438-45.

Meeus J, Van Der Ploeg JD, Wijermans M. 1991. Changing agricultural landscapes in Europe: continuity, deterioration or rupture? In: IFLA conference. Rotterdam, The Netherlands.

Perruchoud D, Kienast F, Kaufmann E, Braker OU. 1999. 20th century carbon budget of forest soils in the Alps. Ecosystems 2:320-37.

Perruchoud D, Walthert L, Zimmermann S, Lüscher P. 2000. Contemporary carbon stocks of mineral forest soils in the Swiss Alps. Biogeochemistry 50:111-36.

Richter DD, Markewitz D, Trumbore SE. 1999. Rapid accumulation and turnover of soil carbon in a re-establishing forest. Nature 400:56-7.

Rounsevell MDA, Annetts JE, Audsley E, Mayr T, Reginster I. 2003. Modelling the spatial distribution of agricultural land use at the regional scale. Agric Ecosyst Environ 95:465-79.

Rounsevell MDA, Regnister I, Araujo MB, Carter TR, Dendonkner N, Ewert F, House JI, Kankaapää S, Leemans R, Metzger MJ, Schmit C, Tuck G. 2006. A coherent set of future land use change scenarios for Europe. Agric Ecosyst Environ 114:57-68.

Rutherford GN, Zimmermann NE, Bebi P, Edwards PJ. 2008. Assessing land-use statistics to model land cover change in a mountainous landscape in the European Alps. Ecol Modell 212:460-71.
Schmid S, Thürig E, Kaufmann E, Lischke H, Bugmann H. 2006. Effect of forest management on future carbon pools and fluxes: a model comparison. For Ecol Manage 237:65-82.

Statistisches Jahrbuch der Schweiz. 1997. Verlag Neue Zürcher Zeitung, Zürich.

Swiss Federal Statistical Office. 2001. The changing face of land use. Land use statistics of Switzerland. Neuchatel: Geostat.

Tasser E, Tappeiner U. 2002. Impact of land use changes on mountain vegetation. Appl Veg Sci 5:173-84.

Thürig E, Palosuo T, Bucher J, Kaufmann E. 2005. The impact of windthrow on carbon sequestration in Switzerland: a modelbased assessment. For Ecol Manage 210:337-50.

Townsend AR, Braswell BH, Holland EA, Penner JE. 1996. Spatial and temporal patterns in potential terrestrial carbon storage resulting from deposition of fossil fuel derived nitrogen. Ecol Appl 6:806-14.

van der Vaart JHP. 2005. Towards a new rural landscape: consequences of non-agricultural re-use of redundant farm buildings in Friesland. Landsc Urban Plan 70:143-52.

VanMechelen L, Groenemans R, VanRanst E. 1997. Forest soil condition in Europe; results of a large-scale soil survey. Technical report. EC; UN-ECE. Brussels, Geneva: Ministry of the Flemish Community.

Vesterdal L, Ritter E, Gundersen P. 2002. Change in soil organic carbon following afforestation of former arable land. For Ecol Manage 169:137-47.

Vorreiter L. 1949. Holztechnisches Handbuch, Band I: Allgemeines, Holzkunde, Holzschutz und Holzvergütung. Wien: Verlag Georg Fromme \& Co. 